\title{
A Morphometric and Morphological Study of mandibular lingula and its Clinical Significance
}

\author{
Sophia $\mathbf{M M}^{1}$, Alagesan $\mathbf{A}^{2}$, Ramchandran $\mathbf{K}^{3}$ \\ ${ }^{1}$ Dr Manavalan Mahima Sophia, Assistant Professor, ${ }^{2}$ Dr. Alagesan Anupriya, Assistant Professor, ${ }^{3}$ Dr.Ramachandran \\ Kalpana, Professor and Head. All are affiliated to Department of Anatomy, Sri Muthukumaran Medical College \\ \&Research Institute, Chennai, India
}

Address for Corresponding: Dr. Manavalan Mahima Sophia, Department of Anatomy, Sri Muthukumaran Medical College \& Research Institute, Chikkarayapuram, Near Mangadu, Chennai, Tamilnadu, India. Email: mahimasophia1982@gmail.com

\begin{abstract}
Aim: Mandibular lingula is a bony projection located on the medial aspect of its ramus. It is very closely related to the mandibular foramen and inferior alveolar nerve and vessels. The aim of the present study is to observe the different shapes, position and height of the lingula in relation to the mandible. Materials and Methods: The study was conducted on 50 adult dry human mandibles (100 sides) in the Department of Anatomy, Sri Ramachandra Medical College \& Research Institute, Chennai. The different shapes of lingula were observed and position and height of lingula in relation to mandible were measured using vernier callipers. Results: The most frequent shape of the lingula observed in our study was triangular (49\%) followed by nodular $(23 \%)$, truncated $(18 \%)$ and assimilated $(10 \%)$ types. The lingula was located at a mean distance of $17.11 \pm 2.32 \mathrm{~mm}$ and $14.86 \pm 2.54$ from the anterior and posterior border of ramus of mandible. The mean distance from the lingula to mandibular notch was $18.71 \pm 3.18 \mathrm{~mm}$ and to the mandibular notch was $30.30 \pm 5.11$ $\mathrm{mm}$. The mean height of the lingula was $7.45 \pm 1.48 \mathrm{~mm}$. Conclusion: The lingula is a very important landmark where mandibular foramen has to be identified in procedures such as inferior alveolar nerve block, bilateral sagittal split ramus osteotomy and intraoral vertical split ramus osteotomy and for excision of nerve in facial neuralgia.
\end{abstract}

Key words: Lingula, Ramus of Mandible, Mandibular Foramen, Inferior Alveolar Nerve

\section{Introduction}

Lingula of mandible is a sharp tongue shaped bony projection located just above the centre of medial aspect of mandibular ramus [1]. Lingula means "little tongue" was described by Johannes-Baptist Spix in 1815 and was therefore named Spix's ossicle or spine or lingula mandibulae[2]. Lingula lies very close to the mandibular foramen which transmits inferior alveolar nerve and vessels that continues along the mandibular canal [3]. The inferior alveolar nerve supplies the pulp of teeth of lower jaw and ends by supplying the lower lip and skin over the chin by its terminal branch, mental nerve which comes out through mental foramen [4]. In about $50 \%$ of adults, lingula forms half to two-thirds of the wall of mandibular foramen and myelo-hyoid line begins from the posterior border of the lingula[5]. Lingula provides attachment to sphenomandibular ligament [6]. Lingula

Manuscript received: $27^{\text {th }}$ Dec 2014

Reviewed: $30^{\text {th }}$ Dec 2014

Author Corrected: $7^{\text {th }}$ Jan 2015

Accepted for Publication: $2^{\text {nd }}$ Feb 2015 acts as an important landmark for identifying the site for injection of local anaesthetics during dental surgical procedures or for excision of nerve for facial neuralgia [7]. Nearly $10-15 \%$ of failure rates of inferior alveolar nerve block may be due to structural variations of the lingula[8].

Lingula acts as an important landmark for common dental surgical procedures such as bilateral sagittal split ramus osteotomy and intra-oral vertical split ramus osteotomy which is done for the correction of dento facial deformities like prognathism, orthognathia and laterognathia. The bone cuts should be made at the level of the tip of lingula to avoid injury to the inferior alveolar nerve. Inaccurate localisation of lingula may result in intraoperative complications such as haemorrhage, fracture and nerve injury[9]. Hence the aim of the present study is to observe the different shapes and position of lingula in dry adult human mandibles and to stress its clinical significance. 


\section{Materials and Methods}

This study has been carried out on 50 adult dry human mandibles (100 sides) in the Department of Anatomy, Sri Ramachandra Medical College \& Research Intitute, Chennai. The shapes of lingula were noted as per the classification given by Tuli et al [1]

1. Triangular - Had a wide base and rounded or pointed apex (Fig.1)

2. Truncated - bony projection appearing quadrangular (Fig.2)

3. Nodular- Entire lingula except apex merged into ramus (Fig.3)

4. Assimilated - Lingula completely incorporated into ramus (Fig.4)
The height and position of lingula were noted by measuring the following distances using vernier calipers.

1. Height of lingula- Tip of lingula to inferior border of mandibular foramen

2. Position of lingula

a. Tip of lingula to the anterior border of the ramus

b. Tip of lingula to the posterior border of ramus

c. Tip of lingula to the coronoid notch

d. Tip of lingula to the base of mandible

The mean and standard deviation (S.D) of each measurement was calculated.

\section{Results}

The present study was conducted on 50 adult dry human mandibles (100 sides). Following are the various findings of the present study

\section{Shape of lingula:}

Table 1: Shape of lingula

\begin{tabular}{|l|l|l|l|l|l|l|}
\hline S.No & Shape & Bilateral & Unilateral & \multirow{2}{*}{ Total } & \multirow{2}{*}{} \\
\cline { 4 - 5 } & & & Right & Left & & \\
\hline 1 & Triangular & 43 & 2 & 4 & 49 & 49 \\
\hline 2 & Nodular & 21 & 1 & 1 & 23 & 23 \\
\hline 3 & Truncated & 12 & 3 & 3 & 18 & 18 \\
\hline 4 & Assimilated & 8 & 2 & - & 10 & 10 \\
\hline & Total & $\mathbf{8 4}$ & $\mathbf{8}$ & $\mathbf{8}$ & $\mathbf{1 0 0}$ & \\
\hline
\end{tabular}

The different shapes of lingula observed in our study has been summarised in Table 1 . The most common type of lingula observed in our study was triangular in $49 \%$ of cases[Fig.1] followed by nodular type in $23 \%$ of cases [Fig.2], truncated type in $18 \%$ [Fig.3] and assimiliated type in $8 \%$ [Fig.4]. Out of $49 \%$ of triangular shape of lingula, $43 \%$ was observed bilaterally and $6 \%$ unilaterally. Out of $23 \%$ of nodular shape lingula, we observed bilateral and unilateral nodular shape in $21 \%$ and $2 \%$ respectively. Out of $18 \%$ of truncated shape lingula, $12 \%$ observed bilaterally and $6 \%$ unilaterally. Out of $10 \%$ of assimilated shape lingula, we observed bilateral and unilateral of this shape in $8 \%$ and $2 \%$ respectively.

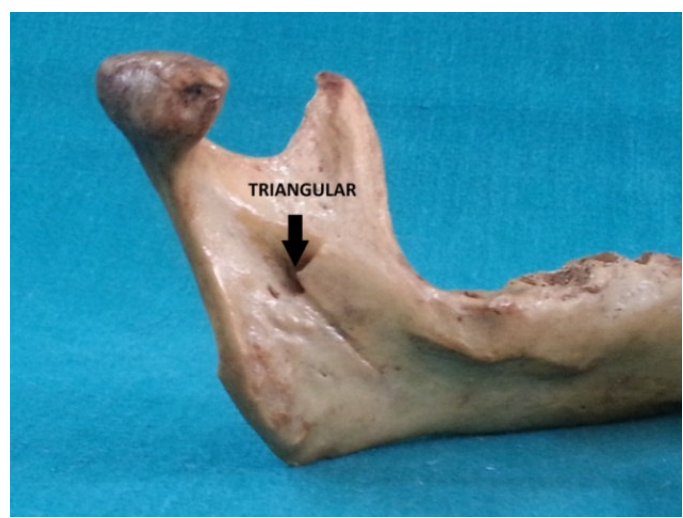

Fig 1: Showing triangular lingula with broad base and pointed apex 


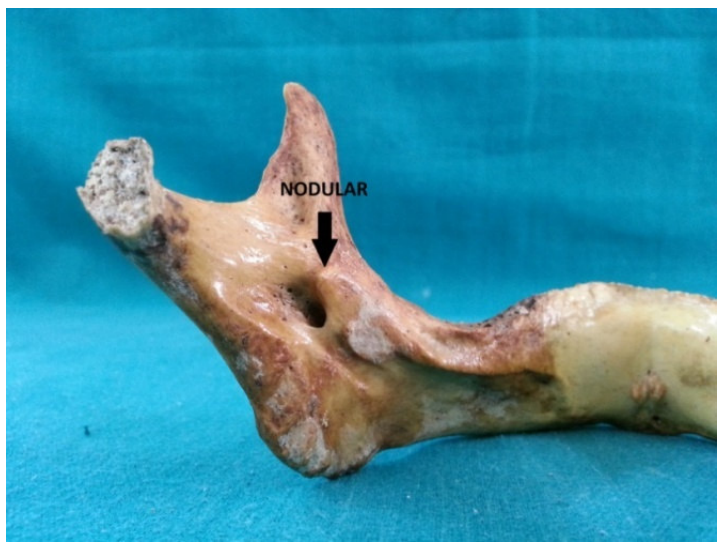

Fig 2: Showing nodular lingula - entire lingula incorporated into ramus except apex

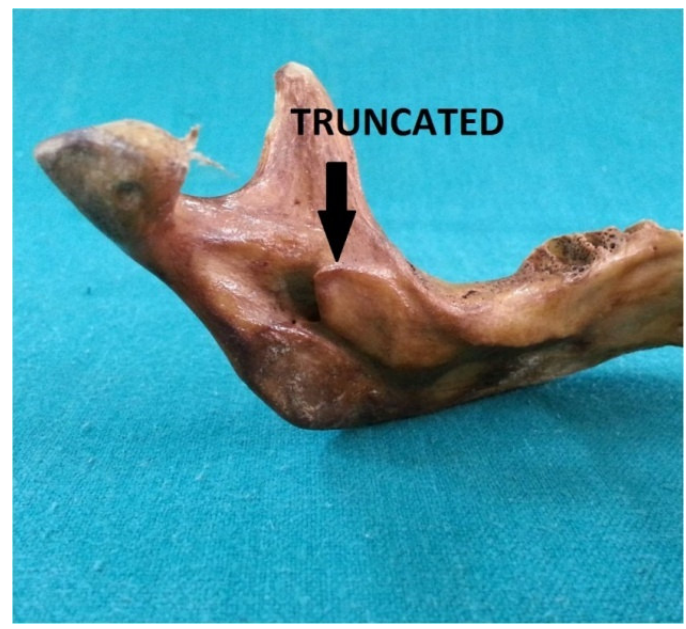

Fig 3: Showing truncated lingula- flat projection with blunt apex

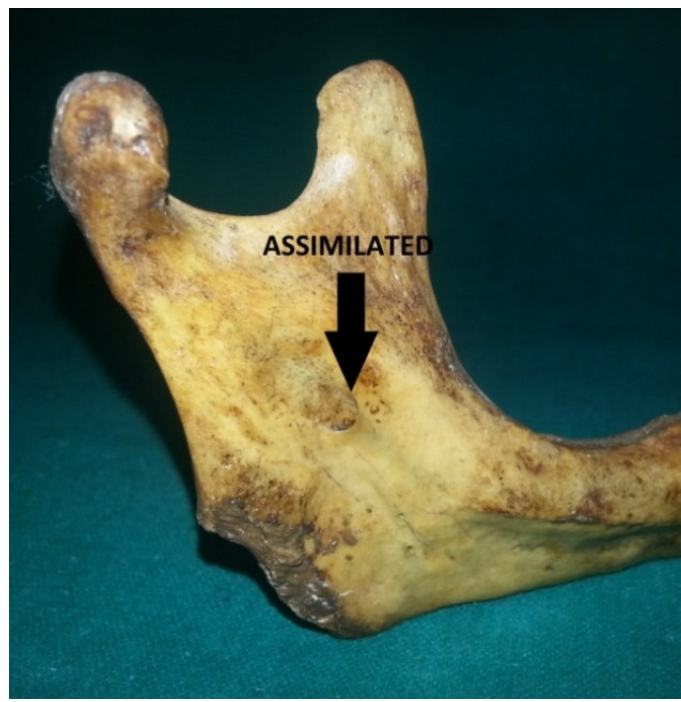

Fig 4: Showing assimilated lingula- entire lingula incorporated into ramus 


\section{Height of lingula:}

Table 2: Height of lingula

\begin{tabular}{|l|l|l|l|l|l|l|l|}
\hline \multirow{2}{*}{ Measurement } & \multicolumn{3}{|c|}{ Right side } & \multicolumn{3}{c|}{ Left side } & \multirow{2}{*}{ AVERAGE } \\
\cline { 2 - 8 } & $\begin{array}{l}\text { Mean } \\
(\mathbf{m m})\end{array}$ & $\begin{array}{l}\text { S.D } \\
\mathbf{( m m})\end{array}$ & $\begin{array}{l}\text { Range } \\
(\mathbf{m m})\end{array}$ & $\begin{array}{l}\text { Mean } \\
(\mathbf{m m})\end{array}$ & $\begin{array}{l}\text { S.D } \\
(\mathbf{m m})\end{array}$ & Range (mm) & \\
\hline Height of lingula & 7.68 & 1.41 & $5.33-9.87$ & 8.02 & 1.56 & $5.35-10.05$ & $7.45 \pm 1.48$ \\
\hline
\end{tabular}

The measurement taken to determine the height of lingula has been summarised in Table 2. The observed range of height of lingula was 5.33-9.87 $\mathrm{mm}$ on the right side and 5.35-10.05 $\mathrm{mm}$ on the left side.

\section{Position of lingula:}

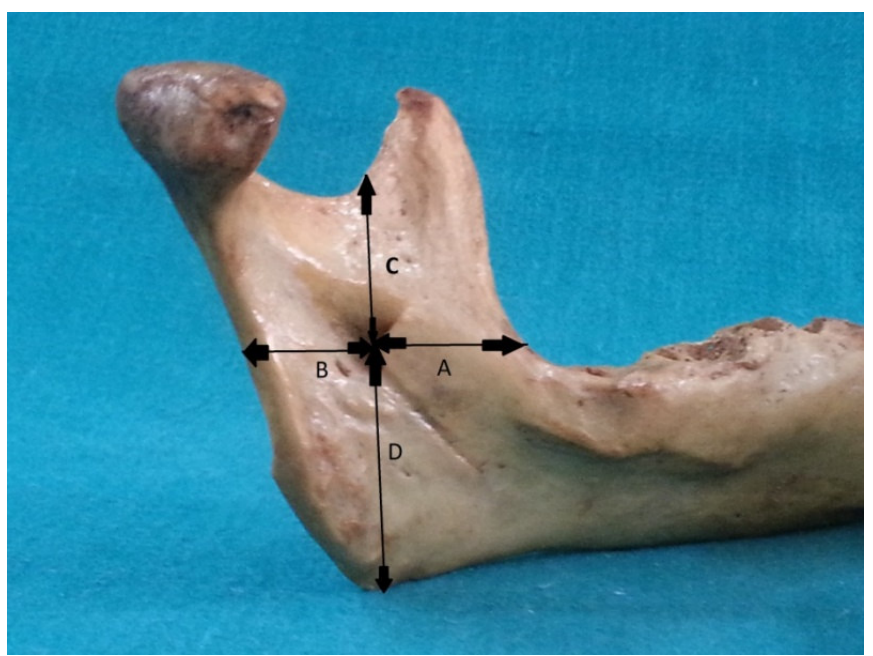

Fig.5: Measurements taken to determine the position of lingual

A- Tip of Lingula to anterior border of ramus, B- Tip of lingula to posterior border of ramus C-Tip of lingula to coronoid notch, D- Tip of lingula to base of mandible

Table 3: Measurements taken to determine the position of lingula

\begin{tabular}{|c|c|c|c|c|c|c|c|c|}
\hline \multirow[t]{2}{*}{ S.No } & \multirow[t]{2}{*}{ Measurements } & \multicolumn{3}{|c|}{ Right side } & \multicolumn{3}{|c|}{ Left side } & \multirow[b]{2}{*}{ Average } \\
\hline & & $\begin{array}{l}\text { Mean } \\
(\mathrm{mm})\end{array}$ & $\begin{array}{l}\text { S.D } \\
(\mathrm{mm})\end{array}$ & $\begin{array}{l}\text { Range } \\
(\mathrm{mm})\end{array}$ & $\begin{array}{l}\text { Mean } \\
(\mathrm{mm})\end{array}$ & $\begin{array}{l}\text { S.D } \\
(\mathrm{mm})\end{array}$ & $\begin{array}{l}\text { Range } \\
(\mathrm{mm})\end{array}$ & \\
\hline 1. & $\begin{array}{l}\text { Lingula to anterior } \\
\text { border of ramus }\end{array}$ & 16.68 & 2.40 & $11.28-21.21$ & 15.08 & 2.19 & $\begin{array}{l}12.38- \\
21.96\end{array}$ & $17.11 \pm 2.32$ \\
\hline 2. & $\begin{array}{l}\text { Lingula to posterior } \\
\text { border of ramus }\end{array}$ & 14.60 & 2.38 & $9.48-21.23$ & 15.13 & 2.71 & $\begin{array}{l}10.69- \\
22.26\end{array}$ & $14.86 \pm 2.54$ \\
\hline 3. & $\begin{array}{l}\text { Lingula to } \\
\text { mandibular notch }\end{array}$ & 18.62 & 3.18 & $13.61-26.25$ & 18.80 & 3.24 & $\begin{array}{l}13.25- \\
24.81\end{array}$ & $18.71 \pm 3.18$ \\
\hline 4 & $\begin{array}{l}\text { Lingula to base of } \\
\text { mandible }\end{array}$ & 29.88 & 5.01 & $23.85-43.20$ & 30.72 & 5.27 & $\begin{array}{l}22.62- \\
39.81\end{array}$ & $30.30 \pm 5.11$ \\
\hline
\end{tabular}

The measurements taken to determine the position of lingula has been summarised in Table 2 and Fig 5 . The mean distance from the lingula to the anterior border of ramus of mandible was $16.68 \pm 2.40 \mathrm{~mm}$ on the right side and $15.08 \pm$ $2.19 \mathrm{~mm}$ on the left side. The mean distance from the lingula to the posterior border of ramus of mandible was $14.60 \pm$ $2.38 \mathrm{~mm}$ (right side) and $15.13 \pm 2.71$ (left side). The mean distance from the lingula to the mandibular notch of mandible was $18.62 \pm 3.18$ on the right side and $18.80 \pm 3.24$ on the left side. The mean distance from the lingula to the base of mandible was $29.88 \pm 5.01$ on the right side and $30.72 \pm 5.27$ on the left side. 
Research Article

\section{Discussion}

Lingula is developed from the Meckels cartilage of first brachial arch which also gives rise to spine of sphenoid and sphenomandibular ligament [10] .

According to standard text books, the shape of the lingula is said to be triangular [11,12]. Nicholson reported the various shapes of lingula but did not describe them[8]. Other than triangular shape, truncated type was described by Hollinshead[13], nodular type was described by Berkovitz et al [14] and the assimilated type shown by Morgan et al[15] . In our study triangular shape was the commonest shape observed.

In the study done by Tuli et al[1] on 165 adult dry mandibles of Indian origin to determine the shape, direction and borders of lingula, the most common type found was triangular (68.5\%) followed by truncated (15.8\%), nodular (10.9\%) and assimilated(4.8\%). In yet another study of Kosithowornchoi et al[16] on 144 adult dry mandibles, the most frequent type observed was truncated (47\%) followed by nodular (23\%), triangular (17\%) and assimilated(13\%). Jansisyanont et al[17] studied 92 dry mandibles of Thai population and found truncated shape in $46.2 \%$ followed by triangular (29.9\%), nodular(19.9\%) and assimilated(4.3\%). Lopes et al[18] studied 80 dry mandibles of Southern Brazil, triangular shape ( $41.3 \%$ ) was most common followed by truncated (36.3\%), nodular (10.5\%) and assimilated (11.9\%). Nirmale et al[19] studied 84 adult dry mandibles and found triangular shape in $47.6 \%$, nodular in $27.97 \%$, truncated in $10.7 \%$ and assimilated in $13.69 \%$. In the present study on 50 adult dry human mandibles of South Indian Population, the most frequent type observed was triangular (49\%) followed by nodular (23\%), truncated(18\%) and the least prevalent type found was assimilated(10\%) which is accordance to the study done by Nirmale et al[19] but contrary to the findings of Varma et al[4]]and Kosithowornchoi et al[16] where truncated shape is the most common and study of Smita et al[20] and Lopes et al[18] where nodular shape is the least prevalent type.

Following is the comparison between the present study and the other studies regarding shapes of lingula (Table 3)

Table 3: Comparison of various studies regarding shapes of lingula

\begin{tabular}{|l|l|l|l|l|l|}
\hline Author & $\begin{array}{l}\text { No.of } \\
\text { Specimens }\end{array}$ & Triangular(\%) & Nodular (\%) & Truncated(\%) & $\begin{array}{l}\text { Assimilated } \\
\mathbf{( \% )}\end{array}$ \\
\hline Tuli et al[1] & 165 & 68.5 & 10.9 & 15.8 & 4.8 \\
\hline $\begin{array}{l}\text { Kosithowornchai } \\
\text { et al[16] }\end{array}$ & 144 & 17 & 23 & 47 & 13 \\
\hline $\begin{array}{l}\text { Jansisyanont et } \\
\text { al[17] }\end{array}$ & 92 & 29.9 & 19.6 & 46.2 & 4.3 \\
\hline Lopez et al[18] & 80 & 41.3 & 10.5 & 36.3 & 11.9 \\
\hline Samanta et al[21] & 124 & 61.6 & 31.6 & 46.6 & 11.6 \\
\hline Nirmale et al[19] & 84 & 47.6 & 27.97 & 13.6 & 10.71 \\
\hline Varma et al[4] & 193 & 13 & 42 & 29 & 6 \\
\hline Smita [20] & 50 & 42 & 10 & 36 & 12 \\
\hline $\begin{array}{l}\text { Padmavathi et } \\
\text { al[22] }\end{array}$ & 65 & 29.23 & 19.23 & 33.84 & 17.70 \\
\hline Smrity et al[23] & 102 & 50 & 11.76 & 33.82 & 2.9 \\
\hline Present study & 50 & 49 & 23 & 18 & 10 \\
\hline
\end{tabular}

The reason for the variation in shape of the lingula is not understood. According to Tuli et al[1], the sphenomandibular ligament which is attached to the tip of the lingula and is also an accessory ligament of temporomandibular joint may have minimal influence in altering the shape of lingula.

The morphometric studies to locate the position of lingula are few and location of lingula also varied among ethnic and racial groups. In the study done by Suwadee et al[24] on 72 adult dry human mandibles of Thai Population, the position of lingula was found $20.70 \pm 2.27 \mathrm{~mm}$ from the anterior border of ramus, $18.88 \pm 3.03$ from the posterior border of ramus , 
$16.41 \pm 3.60$ from the mandibular notch and $35.79 \pm 3.38$ from the base of mandible. In the study done by Samanta et al[21] on 124 dry mandibles of North Indian population, the position of lingula was observed $20.0 \pm 2.4 \mathrm{~mm}$ from the anterior border of ramus, $15.0 \pm 2.7 \mathrm{~mm}$ from the posterior border of ramus and $15.4 \pm 2.7 \mathrm{~mm}$ from the mandibular notch . In yet another study of Padmavathi et al[22] on 65 adult mandibles of South Indian Population, the lingula was located $21.32 \pm 4.12 \mathrm{~mm}, 19.61 \pm 3.30 \mathrm{~mm}, 18.62 \pm 3.71 \mathrm{~mm}$ and $36.05 \pm 4.12 \mathrm{~mm}$ from the anterior border of ramus, posterior border of ramus, mandibular notch and base of mandible respectively and the height of the lingula was $7.41 \pm 2.23 \mathrm{~mm}$. In the present study, the position of lingula was found $17.11 \pm 2.32 \mathrm{~mm}, 14.86 \pm 2.54,18.71 \pm 3.18 \mathrm{~mm}$ and $30.30 \pm 5.11$ $\mathrm{mm}$ from the anterior and posterior border of ramus, mandibular notch and the base of mandible respectively and the height of the lingula found to be $7.45 \pm 1.48 \mathrm{~mm}$. All the measurements are more or less similar to the findings of other studies except the distance between the lingula and the posterior border of the ramus which is different from other studies.

Following is the comparison between the present study and the previous studies regarding shapes

Table 4: Comparison of measurements of height and position of lingula with previous studies

\begin{tabular}{|l|l|l|l|l|l|l|}
\hline Author & $\begin{array}{l}\text { No.of } \\
\text { specimen } \\
\text { s }\end{array}$ & $\begin{array}{l}\text { Lingula to } \\
\text { anterior } \\
\text { border of } \\
\text { ramus (mm) }\end{array}$ & $\begin{array}{l}\text { Lingula to } \\
\text { posterior } \\
\text { border of } \\
\text { ramus(mm) }\end{array}$ & $\begin{array}{l}\text { Lingula to } \\
\text { mandibular } \\
\text { notch(mm) }\end{array}$ & $\begin{array}{l}\text { Lingula to } \\
\text { base of } \\
\text { mandible } \\
\text { (mm) }\end{array}$ & $\begin{array}{l}\text { Height of } \\
\text { lingula } \\
\text { (mm) }\end{array}$ \\
\hline $\begin{array}{l}\text { Suwadee et } \\
\text { al[24](Thai } \\
\text { Population) }\end{array}$ & 72 & $20.70 \pm 2.27$ & $18.88 \pm 3.03$ & $16.41 \pm 3.60$ & $35.79 \pm 3.38$ & - \\
\hline $\begin{array}{l}\text { Jansisyanont etal[17] } \\
\text { (Thai Population) }\end{array}$ & 92 & $20.6 \pm 2.4$ & $18.0 \pm 2.6$ & $16.6 \pm 2.9$ & - & $8.2 \pm 2.3$ \\
\hline $\begin{array}{l}\text { Samanta et al[21] } \\
\text { (North Indian } \\
\text { population) }\end{array}$ & 100 & $20.0 \pm 2.4$ & $15.0 \pm 2.7$ & $15.4 \pm 2.7$ & - & - \\
\hline $\begin{array}{l}\text { Padmavathi et al[22] } \\
\text { (South } \\
\text { population) }\end{array}$ & 65 & $21.32 \pm 4.12$ & $19.61 \pm 3.30$ & $18.62 \pm 3.71$ & $36.05 \pm 4.12$ & $7.41 \pm 2.23$ \\
\hline Present study & 50 & $17.11 \pm 2.32$ & $14.86 \pm 2.54$ & $18.71 \pm 3.18$ & $30.30 \pm 5.11$ & $7.45 \pm 1.48$ \\
\hline
\end{tabular}

A vertical ramus osteotomy should be performed very carefully if the distance between lingula and posterior border of mandibular ramus is less than $15 \mathrm{~mm}$ [17].In the present study the distance between the lingula and the posterior border of mandibular ramus is less than $15 \mathrm{~mm}(14.86 \pm 2.54 \mathrm{~mm})$ and hence a knowledge of such a variation is of utmost significance and will help dental surgeons to plan their procedures and avoid complications.

The knowledge of shape, position and height of lingula is important to oral and maxilla-facial surgeons while doing procedures like bilateral sagittal- split ramus osteotomy, intra oral vertical ramus osteotomy and inferior alveolar nerve block. It is also important in preventing iatrogenic injuries to the closely related nerves and vessels which may lead to nerve paresis and haemorrhages. It is also helpful in anthropology and forensic practice.

\section{Conclusion}

The present study contributes additional information to the available literature regarding the shapes, height and location of the lingula in relation to the mandibular landmarks.

This findings may be helpful for dental surgeons to locate the lingula and to preserve important structures nearby while doing surgical procedures around the lingula region.

Funding: Nil

Permission from IRB: Yes

Conflicts of interest: The authors report no conflicts of interest 


\section{References}

1. Tuli A, Choudhry R, Choudhry S, Raheja S, Agarwal $\mathrm{S}$. Variation in shape of the lingula in the adult human mandible. J Anatomy. 2000; 197(2):313-317.

2. Dobson J. Anatomical Eponyms. $2^{\text {nd }}$ Ed. Edinburg, London: E and S Livingstone.1962; p.194.

3. Tsuji Y, Muto T, Kawakami T, Takeda S. Computed tomographic analysis of the position andcourse of the mandibular canal: Relevance to the sagittal split ramus osteotomy. Int J Oral Maxillofac Surg. 2005; 34: 243246.

4. Varma CL, Sameer PA. Morphological variants of Lingula in south Indian Mandibles. RRJHMS , January to March 2013; 2(1):31-34.

5. Fabian FM. Observation of the position of the lingula in relation to the mandibular foramen and the mylohyoid groove. Ital J Anat Embryol. 2006; 111: 151-158.

6. Gardner M. Basic anatomy of the head and neck. London: Lea \&Febiger. 1992; 383

7. Basmajian JV Grant's Method of Anatomy, 10th edn. Baltimore, London: Williams \& Wilkins.1980; p.474.

8. Nicholson ML. A study of the position of the mandibular foramen in the adult mandible. The Anatomical Record 1985; 212: 110-112.

9. Behrman SJ. Complications of sagittal osteotomy of the mandibular ramus. J oral surg. 1972; 30: 554-561.

10. Moore KL, Persaud TVN. The Developing HumanClinically Oriented Embryology, Seventh edition, Saunders, Philadelphia. 2003. p: 204.

11. Sinnatamby CS. Mandible, Osteology of skull and hyoid bone. Last's Anatomy, Regional and Applied. Eleventh edition. Churchill Livingstone, Elsevier. 2006. p. 532-533.

12. Standring S, Collins P, Healy JC, Wigley C, Beale TJ. Mandible: Infratemporal and pterygopalatine fossae and temporomandibular joint. Gray's Anatomy - The Anatomical Basis of Clinical Practice, Fortieth edition. Churchill Livingstone, Elsevier. 2008. p. 530-532.
13. Hollinshead W H. Textbook of Anatomy. First edition. Calcutta, India: Harper and Row.1962; p: 855856.

14. Berkovitz BKB, Holland GR, Moxham BJ. Colour atlas and textbook of oral anatomy. Second edition. London: Wolfe Medical Publication. 1978; Pp:15.

15. Morgan DH, House LR, Hall WP, Vamuas S J. Diseases of temporomandibular apparatus. Second edition. Saint Louis: CV Mosby. 1982 ; Pp: 19

16. Kositbowornchai S, Siritapetawee, Damrongrungruang T, Khongkankong W, Chatrchaiwiwatana S, Khamanarong K, Chanthaooplee T. Shape of the lingula and its localization by panoramic radiograph versus dry mandibular measurement. Surg Radiol Anat. 2007;29(8):689-694.

17. Jansisyanont $\mathrm{P}$, Apihasmit S, Chompoopong. Shape, height and location of the lingula forsagittal ramus osteotomy in Thais. Clin Ana. 2009; 22:787-793.

18. Lopes PTC, Periera GAM, Santos AMPV. Morphological Analysis of the lingula in dry mandibles of individuals in Southern Brazil. J Morpholog Sci. 2010; 27(3-4):136-138.

19. Nirmale VK, Mane UW, Sukre SB, Diwan CV. Morphological Features of Human Mandible. Int $\mathrm{J}$ of Recent Trends in Sci Technol. 2012; 3 (2): 38-43.

20. Smita T. Variations in the Morphological appearance of lingula in dry adult human mandibles, Int J of Cur Res Rev. 2013; 5(24):41-45

21. Samanta PP, Kharab P. Morphological Analysis of Lingula in Dry Adult Human Mandibles of North Indian Population. J Cranio Max Dis 2012;1: 7-11.

22. Padmavathi G, Varalakshmi KJ, Suman T, Roopashree K. A Morphological and morphometric study of the lingula in dry adult human mandibles of South Indian origin and its clinical significance. International Journal of Health Sciences and Research. 2014; 4(6): 56-61. 
23. Smrity G, Krishna P. Morphological analysis of the lingula in dry mandibles of individuals in North India. Journal of Dental and Medical Sciences. 2014;13(1):4-6
24. Suwadee K, Mookdha S, Teerasak D, Waranyoo K, Supaporn C, Kimaporn K, Tanarat C. Shape of the lingula and its localisation by panaromic radiograph versus dry mandibular measurements. Surg Radiol Anat. 2007; 29:689-694.

\section{How to cite this article?}

Sophia MM, Alagesan A, Ramchandran K. A Morphometric and Morphological Study of mandibular lingula and its Clinical Significance. Int J Med Res Rev 2015;3(2):141-148. doi: 10.17511/ijmrr.2015.i2.025. 